\title{
FRONTLINE RESPONSE TO HIGH IMPACT DOMESTIC VIOLENCE IN BULGARIA
}

\author{
MARgarita VASSILEVA \& THIERry DELPEUCH \\ Université Grenoble Alpes, Sciences po Grenoble, CNRS - UMR PACTE, \\ Saint-Martin-d'Hères, France. \\ E-mail: margarita.vassileva@umrpacte.fr; thierry.delpeuch@umrpacte.fr
}

Abstract According to the NGO Women Against Violence Europe, an estimated 30 per cent of women in Bulgaria suffer from domestic abuse every year. Thirty-five women were murdered in the context of domestic violence in 2018. The mistrust of law enforcement and the justice system inherited from the communist regime discourages victims from seeking assistance from the police and the judiciary. The issue of violence against women surfaced in the government's agenda due to the debates around the ratification of the Istanbul Convention, which was ultimately rejected. The country policies are characterised by a lack of change in the legal frameworks, a lack of official data, a lack of sufficient financing from the state budget, and a lack of established procedures for handling domestic violence cases. Ineffective coordination between institutions, the failure to make official statistics publicly available, the lack of a national register of acts of domestic violence, the requirement of proof of systemic violence to initiate criminal proceedings, and the lack of resources to support NGOs are all obstacles that result in a high number of acts of domestic violence that goes unaddressed by the courts. NGOs are at the forefront of the fight against domestic violence.

Keywords:

domestic violence, Bulgaria, interagency cooperation, victims, NGO, police 


\section{Description of the country regarding domestic violence}

In Bulgarian society, domestic violence (DV) is a problem that is frequently encountered. According to NGO data, 1 million (i.e. one out of every three) women in the country have been victims of domestic violence. However, only $14 \%$ report their assaults to the police, and they do not believe they will receive any support. The challenges in the field of DV also stem from the fact that gender difference ${ }^{1}$ is firmly entrenched wherever traditional roles persist. Thus, according to a survey by Eurobarometer (2017), respondents in Bulgaria are the most likely in Europe to stereotype based on gender: $81 \%$ think that the most important role a woman has is to take care of her home and family and that a man's most important role is to earn money; $32 \%$ think it is not acceptable for men to cry. According to the Women Against Violence Europe organisation, an estimated 900,000 women (30\%) in Bulgaria suffer from domestic abuse every year. Thirty-five women were murdered in the context of domestic violence in 2018.

Largely ignored by the state for many years, the issue of violence against women surfaced in the government's agenda due to the planned ratification of the Istanbul Convention. On 21 April 2016, Bulgaria signed the European Council's Action against violence against women and domestic violence (Istanbul Convention), although it has not ratified it. After long months of heated discussions in the public arena, conservative and nationalist circles and Orthodox and Muslim religious leaders joined forces against the text accusing it of relying on gender theories. On 27 July 2018, the Bulgarian Constitutional Court declared that the Istanbul Convention does not conform to the Bulgarian Constitution because the convention's definition of "gender" as a social construct " relativizes the borderline between the two sexes male and female - that is biologically determined". "If society loses the ability to distinguish between a woman and a man, the fight against violence targeting women will remain a formal but unachievable task", the statement read.

\footnotetext{
1 "If a man can't slap his wife, he's not a man": Man interviewed in Sofia, February 2019.

2 Constitutional Court of the Republic of Bulgaria (Конституционен съд на Република България), Decision No 13 of 23 July 2018: http:// constcourt.bg/bg/Acts/GetHtmlContent/f278a156-9d25-412d-a064-6ffd6f997310
} 
Since then, European ideas and initiatives in the field of women's rights have been seen by a large part of the population as the result of a degraded and harmful Europe. Many demonstrations were organised against the Istanbul Convention and the Strategy for the Protection of Children. The protagonists of these movements declared themselves opposed, on the one hand, to the rise of alternative concepts targeting sexual orientation and, on the other hand, to the intervention by the state in the family sphere and, in particular, to the prerogatives to place a child in a social structure. A whole reactionary vocabulary has appeared in the public space: The word "gender" has been imported into the Bulgarian language as "Ажендър" [djendar] but means a person with an "abnormal" sexual orientation. Its connotation has become extremely negative. The way the non-ratification of the IC was viewed has divided the country into two opposing camps. This discord has pitted the city against the countryside, the people belonging to the LGBTQ community against those who do not tolerate them. As a result, institutions and non-governmental organisations working in the field of the family have difficulty finding partners and participants to support their activities.

The lack of reliable official data on violence against women is considered one of the most significant problems of Bulgarian criminal procedure and policy. The main reason is that Bulgaria does not have an automatic information system to collect and process data on domestic violence. This function is part of the Integrated Information System for Action against Crime, which is currently being developed. Various institutions use their own information systems. For example, the Ministry of the Interior collects data on crimes such as murder, rape, sexual violence, bodily harm and other forms of violence that can be based on gender. Surveys on DV are generally conducted as part of research projects and are, therefore, not long-term. Projects are carried out by partners, but competition may also hinder the flow of exchanges. In the end, the information is insufficient and poorly organised on the Internet. Bulgaria is one of the countries for which Eurostat has no data on femicides. 


\section{Legal changes regarding domestic violence}

\section{Law on Protection against Domestic Violence: the protection of victims through civil proceedings}

The Bulgarian Law on Protection against Domestic Violence (LPDV) ${ }^{3}$ was adopted in 2005 and is considered a breakthrough in countering this growing phenomenon. ${ }^{4}$ The law offers direct remedies against acts of domestic violence by means of a civil law procedure before civil courts within relatively short time frames. Authorities cannot act in an ex officio capacity, and the launch of proceedings greatly depends on the victim's willingness to lodge a complaint. All victims of domestic violence may seek protection under the law from the regional court.

Court proceedings must be initiated by the victim, who must submit a written motion which contains a personal declaration regarding the violence committed. The motion is submitted within one month of the act of domestic violence, and on the day of submission the court schedules an open hearing to take place within one month.

Admissible evidence during the proceedings includes actions taken by the Social Assistance Directorates, consulting doctors and/or psychologists, as well as documents from social service providers and certified copies of written evidence from the police and other authorities. If there is no other evidence, the court issues a protection order based solely on the victim's declaration.

The law provides for psychological consultation and practical aid, which are offered primarily by NGOs, as well as medical and legal aid, which are regulated by special laws. The law does not require victims to receive legal representation or advice. In practice, victims are most often represented or advised by attorneys in the proceedings on protection orders against domestic violence and interim measures. State-provided legal aid in the strict sense is regulated by the specific Law on Legal

\footnotetext{
${ }^{3}$ National Assembly of the Republic of Bulgaria (2005). Закон за защита от домашното насилие [Law on Protection against Domestic Violence] (State Gazette (SG) 27 of 29 March 2005). Sofia, National Assembly of the Republic of Bulgaria.

${ }^{4}$ Number of victims of DV who have obtained a protection order: 2,121 (2015), 2,323 (2016), 2,440 (2017), 2,981 (2018). Source: GDNP, April 2019.
} 
Aid. ${ }^{5}$ Recently, its scope prior to the start of proceedings (consultation and preparation of documents) was significantly broadened to include, in addition to indigent persons and families, children at risk and victims of domestic violence who do not have sufficient funds but would like to be represented by an attorney.

Members of NGOs point out several problems with victims contacting the police as the first authorities: In some cases, police authorities refuse to accept oral or written complaints about domestic violence and directly refer the victims to NGOs or the court; in many cases, registration numbers of complaints are not given or are significantly delayed, which hampers the protection order procedure, since complaints to police are important evidence to be attached to the motion in court.

The directors of local Social Protection Directorates, who can petition the court for protection orders, rarely use this opportunity. By contrast, some police departments prepare petitions for protection orders, even though they are not one of the entities that can submit such petitions, which delays court proceedings. Social workers' reports, which are prepared as part of protection order proceedings, often contain general information on the families' social situation that is not relevant to those specific proceedings, which further hampers victims' protection.

Medical certification of sustained trauma is an important element of proving domestic violence committed during protection order proceedings, but general practitioners, who are specifically empowered by law to issue such certificates, often refuse to do so, while forensic doctors' certificates are expensive, and allegedly no specialists on duty are available over weekends and during holidays. At the same time, certificates by general practitioners are sometimes ignored by the court, and psychological violence is frequently punished less severely in terms of the length of protection measures. If the partners do not live in cohabitation, the victim cannot practically obtain a protection order. In addition, cohabitation can be difficult to prove. In addition, LGBTI partnerships do not enjoy legal recognition in Bulgaria, so they do not fall under the scope of the law.

\footnotetext{
${ }^{5}$ Law on Legal Aid (Закон за правната помощ) (2005). Promulgated in SG 79 of 4 October 2005, in force since 1 January 2006, latest amendments in March 2013. http://lex.bg/bg/laws/ldoc/2135511185
} 
If the court honours the motion, it issues a protection order with one or more of the following protection measures:

- the perpetrator is obliged to refrain from committing domestic violence,

- the perpetrator is removed from the co-habited home for an amount of time determined by the court,

- the perpetrator is prohibited from approaching the victim, his/her place of living, work of social contacts and recreation under terms and conditions determined by the court,

- the child is temporarily placed with the victimised parent or the parent who is not alleged to have committed the violence under terms and conditions determined by the court, provided this does not go against the interests of the child,

- the perpetrator of the violence is obliged to take part in specialised programmes,

- victim is referred to rehabilitation programmes,

- a fine of 200 to 1,000 leva (€100-€500) is also imposed.

Bulgarian law also has an order for immediate protection, which is issued within 24 hours after a motion is submitted if the latter contains evidence of direct, immediate or subsequent danger to the victim.

In court, offenders and victims are often invited to reach an agreement, as in an ordinary civil case, which eliminates the victim's motivation to seek protection via a protection order. Sometimes, in procedures for orders for immediate protection, the measure of temporarily housing the child with the victimised parent (the parent who has not committed the violence) is allegedly not imposed because of a lack of data on the violence directed at the child, despite the latter being a witness to the violence and, therefore, a victim. Thus, victims are left with the alternative to stay with the children or take care of their own security.

Practitioners argue that many courts require domestic violence to be proved beyond a reasonable doubt, which is an excessively high burden of proof that puts the onus entirely on the victim. 
One explanation for this situation would be the abuse of victims' rights, which some complainants would like to benefit from. For example, according to the family judges we met in Sofia, a significant percentage of complainants (between $50 \%$ and $60 \%$ in divorce proceedings use the charge of domestic violence. Often, it is the lawyers who advise their clients to take this approach in order for them to win their cases.

As noted by NGO professionals, a common problem for all protection orders is that they very often simply repeat the provisions of the respective law without any specification, which makes it difficult to enforce them. Judges also note that the measures that protection orders, such as obliging the offender to attend specialised programmes, are inapplicable in practice because of a lack of such programmes and the insufficient number of professionals in that field.

Protection orders are subject to immediate execution. The initiative to notify and prove the potential violation of an order lies wholly with the protected persons.

There is no central register of protection orders for domestic violence in Bulgaria; thus, police officers who are called to the scene do not have advance information about them or that they have been violated.

The police are insufficiently aware of its powers and obligations related to monitoring protection orders. According to NGO professionals, the police often refuse assistance to victims in cases of orders for immediate protection and, instead, wait for the original of the order to be sent officially to them or for the offender to be served with a copy. Reportedly, the police are also uncooperative in cases repeated abuses. NGO professionals claim that non-compliance rarely leads to serious consequences for the offender. The police do not use its powers effectively enough and consider violations a "private" or "family" matter, especially in smaller towns or villages where people know each other, and the protection offered to such victims is largely insufficient.

In the view of a number of practitioners, the sanctions in response to violations of protection orders against DV are not effective in terms of severity and execution. Non-compliance with such orders is criminalised, but criminal proceedings are not frequent, and punishment is not serious enough. 


\section{Reforms of the criminal justice system}

Crimes are prosecuted by the State through the public prosecutor, who collects evidence and brings charges. There, however, systematic violence is required. That is, evidence of three prior acts of domestic violence must be collected. Often victims do not complain to the police and there may have been a pattern, but no evidence was collected. The Criminal Code treats the murder of a mother, father, biological child, pregnant woman or minor as an aggravated case of murder. Any bodily injury of a mother, father, pregnant woman or minor in a manner that is especially torturous for the victim is also an aggravated case. However, light bodily injuries, even in the cases mentioned above, as well as light and medium bodily injuries, are tried only if the victim lodges a complaint. Sexual crimes stemming from acts of domestic violence can also be prosecuted and tried. Bulgarian law does not define rape in the marital context.

As the Bulgarian Constitutional Court judged the Istanbul Convention to be unconstitutional, legislative amendments were adopted by Parliament to strengthen women's protections against violence. Acts of domestic violence as such were criminalised under the Bulgarian Criminal Code. ${ }^{6}$

The most important amendments to the Criminal Code concerned the significant increase in prison sentences and fines for failing to comply with the court decision. These amendments were a step towards the ex officio penalisation of all medium bodily injuries that affect relatives and spouses. Stalking and forced marriages were also criminalised. The amendments made it possible to inform a victim who has special protection needs if the suspect/accused is released or escapes from detention in custody or in prison. Non-compliance with domestic violence protection orders became subject to aggravated punishment.

In cases in which the requirements of the law for crimes committed under the condition of domestic violence are not met, the prosecutor's office shall instruct the victim to initiate proceedings by complaint. This delays the proceedings against the perpetrator. This creates additional risks for the victim and discourages the victim.

\footnotetext{
${ }^{6}$ National Assembly of the Republic of Bulgaria (2019). Amendments and Supplements to the Criminal Code Act (Закон за изменение и допьлнение на Наказателния кодекс), 22 February 2019. Available at http://dv.parliament.bg/DVWeb/showMaterialDV.jsp?idMat=134676
} 
The burden of proof falls on the victim. Victims often do not have the economic means to do so.

As the first actor in contact with victims and perpetrators of DV, the police suffer from weaknesses that prevent them from effectively solving DV cases. According to one police officer, these weaknesses are: "the lack of regulations on the coordination of institutions concerned with the Law on Protection against DV; the need for amendments in the Law on Protection against DV, the Penal Code and the Code of Criminal Procedure in order to criminalize certain DVs; the lack of officers specialized in working with DV victims ; the lack of methodology and training in risk assessment; the lack of targeted funding for DV protection projects; the lack of work programs for DV perpetrators; the lack of shelters for DV victims.

Concerning the risk assessment of DV, currently neither the police nor NGOs have the tools to evaluate the probability of a violent situation. The qualification and skills of the police officers who go to the address where the domestic violence was committed are relied on. In fact, the police officers' expertise in handling collected and existing information is the decisive factor.

The Regulations on the Organisation of the Work of the Prosecutor's Office signed by the Attorney General on 30 April 2018 specify how to conduct preliminary investigations to assess the risk of the perpetrator committing murder or repeating the acts of violence. These are internal notices whose application remains ineffective.

Victims of criminalised acts of domestic violence would most often fall within the scope of the Law on Assistance and Financial Compensation to Victims of Crime $(\mathrm{LAFCVC})^{7}$ in case of murder; intentional grave bodily injury; carnal abuse and rape that resulted in serious health problems; as well as other serious intentional crimes resulting in death or grave bodily injury. The LAFCVC has been criticised for being too restrictive in how it regulates the provision of financial compensation. The latter is only given after the entry into force of the sentence or after proceedings have been terminated, and it does not provide for any pre-payments for urgent expenses. The financial compensation request is submitted to the regional governor for the place

\footnotetext{
${ }^{7}$ National Assembly of the Republic of Bulgaria (2006): Закон за подпомагане и финансова компенсация на постраАали от престьпления [Law on Assistance and Financial Compensation to Victims of Crime] (SG 105 of 22 December 2006), Sofia: National Assembly of the Republic of Bulgaria.
} 
where the victim currently resides or to the National Council for Assistance and Compensation for Victims of Crime within two months of the entry into force of the sentence. It is accompanied by supporting documents, which often create evidentiary difficulties for the victims. It is reviewed by the council's expert committee, and the council adopts a decision that cannot be appealed.

The LPDV stipulates that the court may decide on measures for the perpetrator of domestic violence by requiring him or her to participate in specialised programmes, but in practice, after the court decision, the perpetrator is expected to visit the centres offering this type of service. If the perpetrator of domestic violence is absent from these courses on two occasions, the NGO must immediately refer the matter to the Prosecutor's Office so that it can initiate preliminary proceedings: Under Article 296 of the Criminal Code, failure to comply with the court's decision is a criminal act. The Ministry of the Interior has no information on this subject because participation in programmes for perpetrators of domestic violence is de facto voluntary with the presumption that the programme is effective and the perpetrator will no longer commit such acts. Thus, if there is no report of the perpetrator committing another act of DV, the police do not receive any further information on him. Usually, the obligation for perpetrators to attend psychologists does not change the former's self-perception. According to the victims, systematic violators require not psychological but psychiatric treatment.

\section{National policy and inter-agency coordination}

The main institutions involved in combatting domestic violence:

- Ministry of Interior, through the Prevention Directorate in the Security Police General Directorate, as well as regional directorates (28) and district police departments,

- Ministry of Justice, through its legislative activity and the domestic violence-related project funding of NGOs,

- Courts, involved in adopting protection measures through their civil panels and, through their criminal panels, in trying DV-related criminal acts and violations of DV restraining orders,

- Prosecutor's Office, involved in prosecuting violations of DV restraining orders and DV-related criminal acts, 
- Ministry of Labour and Social Policy,

- Social Assistance Agency and its local directorates,

- State Agency for Child Protection, responsible for coordinating all child protection policies and actions,

- Ministry of Health.

Each year, the Council of Ministers adopts a National Programme for Prevention and Protection against Domestic Violence based on the Law on Protection against Domestic Violence. The programme was first initiated in 2011 and includes actions planned for the coming year, organisations responsible for implementing them, funding sources, implementation timeframes and expected results.

Since 2011, the National Programme for Prevention and Protection from DV has required an annual report on its implementation. However, no official document has been published. Despite the requirement to gather and analyse in detail the data on work with the Law on Protection against DV, there are no statistics under uniform criteria on that topic. This failure is partly remedied by the NGOs' activity reports and European projects in which Bulgarian institutions and NGOs participate. The Animus Association Foundation, the Bulgarian Gender Research Foundation and the Centre for the Study of Democracy have published the most important surveys in this regard. They are all primarily supported by European funds. These are multidisciplinary studies in which the legal approach predominates. Other more targeted studies analyse measures against DV in the context of business, schools, honour crimes, etc.

The official Internet sites of the institutions involved in implementing the National Programme contain no published reports, analyses or independent monitoring reports on the implementation of the programme.

The National Programme is developed by the National Police General Directorate and falls under the responsibility of the national coordinator of policy against DV. Other institutions play a very small role in how the programmes are drafted, and the national coordinator ${ }^{8}$ carries out this task without the full support of the public stakeholders concerned in the fight against DV.

\footnotetext{
${ }^{8}$ Interview, Sofia, February 2019.
} 
In 2015, the National Programme incorporated the creation of a workgroup tasked with drafting amendments to the methodological instruction set in the Law on Protection against Domestic Violence for police authorities. The goal was to introduce a unified approach to the work of police officers in applying the Regulation for Implementation of the Law on Protection against Domestic Violence. This initiative has not been implemented either.

According to the law, there should be cooperation between the Ministry of the Interior and the Ministry of Labour and Social Policy, which should take place through an exchange of information on domestic violence protection requests and on the execution of protection measures and programmes on the prevention of and protection against domestic violence, as well as common actions. Under common actions, each local social assistance director should notify police authorities about the location of each act of domestic violence or violation of a domestic violence restraining order. Police authorities must notify the local social assistance director of every domestic violence case involving a minor or juvenile, a person of limited legal capacity or with disabilities. Twice a year, social assistance structures under the Ministry of Labour and Social Policy provide police authorities with information regarding the registered social assistance providers best suited to treating DV victims on the territory they are responsible for.

In 2012, a multi-agency working group with the Ministry of Justice, supported by Animus Association Foundation, developed a draft coordination mechanism to support victim of DV. The group involved representatives from the Ministry of the Interior, the Ministry of Labour and Social Policy, the Ministry of Education and Science, the Ministry of Youth and Sport, the Ministry of Health, the State Agency for Child Protection and the Agency for Social Assistance. The draft coordination mechanism suggests a framework for cooperation between state institution professionals, NGOs and municipalities in order to standardise, combine and coordinate their respective interventions.

The coordination mechanism includes measures in three areas:

- notification and referral, including identification of the victim, risk assessment and safe referral, 
- protection measures, e.g. through the involvement of the police and child protection departments, medical aid, crisis interventions, placement in crisis centres and so forth in the case of direct and imminent danger and consultation on victims' rights, psychological aid and social advocacy in the case of potential risk,

- social inclusion, i.e. long-term support after the violence has stopped, including psycho-social consultation and psycho-therapeutic work, building skills for the labour market, social consultation, advocacy and active social work.

Elaboration of the coordination mechanism should have been a significant step in the policy response to domestic violence, but the document has still not been signed by the ministers of the responsible institutions. In drafting the mechanism, the Ministry of Health insisted on removing text related to the medical specialists' responsibility for: assessing the risks; alerting any DV victims; filling in the DV report form or taking concrete action when witnessing domestic violence. Evidence suggests that women who have been subjected to violence seek health care and identify medical specialists as the professionals they would trust most when disclosing the abuse. Improvement of existing policies can be achieved only if the Ministry of Health plays a significant role in the process of supporting domestic violence victims.

Lack of a full-scale evaluation of existing policies and strategies hinders the assessment of the policies mentioned above. However, it can be seen that domestic violence policy is implemented in very different ways depending on the institution and on the location. Fragmented and uneven services and regional discrepancies result in varying levels and quality of the response to DV victims.

\section{NGO as main stakeholders in responding to high impact domestic violence}

NGOs are at the forefront of the fight against DV, and thanks to their activities the phenomenon is starting to be taken seriously. They are also the main providers of services, training and analysis related to DV. NGOs working on domestic violence issues keep well-updated databases of relevant information and advice for DV victims, as well as current methodologies and surveys for use by professionals in the 
field. The functioning of NGOs is largely based on European grants, which focus on partnership projects.

Victims should first turn to NGOs such as Animus, Bulgarian Lawyers for Human Rights, etc. to receive psychological, moral and material support, as well as shelter. In this way, cases can be registered so that there is evidence of systematic violence. Such a non-profit association should be able to file a report with the court to initiate proceedings to protect the victim under the PLDV. ${ }^{9}$

An interdepartmental workgroup of the Agency is developing a methodology for providing crisis centre services for Social Assistance. According to the legal definition contained in the Regulation for Implementation of the Law on Social Assistance (RILSA), a "crisis centre" is a social service package for victims of violence, trafficking or other form of exploitation. The service is provided for a period of six months and focuses on offering individual support, meeting everyday needs and providing legal consultation and socio-psychological help when immediate intervention is required, including mobile expert teams trained in crisis intervention. The relevant RILSA regulations provide for immediate and mandatory support to victims of domestic violence who seek help.

Crisis centres in Bulgaria do not have any specific profiles according to the different types of violence. In practice, these centres are distinguished based on the type of target group they service: Across the country, there are 21 State-funded crisis centres for victims of violence, with a total capacity of 214 slots in 15 regional centres, ${ }^{10}$ and there are nine "Mom \& baby" cells, 15 centres for children and six crisis centres for women who have been victims of DV. The latter also accommodate mothers with children and have a total of 64 places. Crisis centres only provide social services: emergency medical and nursing care, crisis intervention, forensic evidence collection, medical follow-up, medical counselling and referral to community resources. The services that the centres provide to victims are mainly individual in nature and reflect the specific needs of the particular person. The services are provided free of charge. Currently, the number of crisis centres is insufficient, the places are quickly filled, and the victim often has to be moved from one centre to another. In addition, owing to a lack of regulation and resources, the police cannot

\footnotetext{
${ }^{9}$ Interview, prosecutor, Sofia, May 2020

${ }^{10}$ Burgas, Varna, Veliko Tarnovo, Vidin, Montana, Pazardjik, Pernik, Pleven, Plovdiv, Ruse, Silistra, Stara Zagora, Sofia, Sofia proper, Shumen
} 
guarantee their safety nor the permanent protection of victims in crisis centres. When resources are scarce and it becomes problematic to transport the victims, police officers may work with NGOs to transport victims and place them in shelters without this being part of their immediate obligations. Some crisis centres are funded by municipalities as part of government action plans, but it is clear that the scope of such services is not sufficient to provide care at the local and national levels.

While the State does not provide sufficient assistance to victims of domestic violence, non-governmental organisations with a high level of national activity work with women. The participation of the NGO sector in assisting domestic violence victims is substantial. In fact, specialised NGOs offer legal advice and representation - to the extent their resources and funding permit - to victims within proceedings for protection orders against DV.

Since 2009, the Ministry of Justice has financed projects by NGOs that involve specialised programmes for perpetrators and victims and work with the judiciary and police to monitor the implementation of the law, as well as publications. NGOs involved in countering DV take part in developing the National Programmes for Prevention and Protection against DV and are listed as major partners in each of them. They also exchange information and undertake common action with institutions. ${ }^{11}$ The NGOs' main role in assisting domestic violence survivors is to provide social services (crisis centres and other specific services, such as social, legal and psychological aid and support). They are involved in Prevention Centres, which are structures on the local level that are co-organised by the MI, municipalities and civic organisations and tasked with countering a number of unlawful acts, including domestic violence. Civic organisations also participate in ad hoc inter-agency structures at the local level. Examples include the Expert Council against DV in Silistra $^{12}$ and consultative councils with the mayor and regional governor of Pernik. The leading NGOs involved in countering domestic violence have formed an Alliance for Protection against gender-based violence. Since its establishment in

\footnotetext{
${ }^{11}$ For example, one of the most recent (September 2018) common initiatives was the implementation of the online platform EMPROVE to provide information and help to DV victims. Thanks to a personalised link, psychologists can communicate with subscribers while the latter can remain anonymous. The objective is to encourage women victims of DV to file a complaint. However, the results have been inconclusive due to the lack of direct human contact. Interview, Sofia, February 2019.

12 Silistra regional administration (2014). В Силистра властта и институциите с Експертен съвет срещу домашното насилие [Silistra authorities and institutions create Expert Council against Domestic Violence]. Silistra, Silistra Regional Administration.
} 
2009, the members ${ }^{13}$ of the alliance have provided interdisciplinary services to women victims of DV at eight locations in Bulgaria and worked on proposing legislation, monitoring the implementation of the legislation and training professionals. Each year, an average of 3,000 women request psychological support from these organisations.

In 2011, the Bulgarian Centre for Gender Studies Foundation in partnership with Animus Association Foundation implemented a project entitled "Disclosure and provision of a set of innovative services in the community to prevent and tackle social exclusion of adult victims of domestic violence in the cities of Sofia, Plovdiv and Dimitrovgrad!" It was funded through the Human Resources Development Programme 2007-2013 under the Social Services for Social Inclusion framework. Over the course of the project, the Animus Association Foundation developed an innovative programme for prevention and risk management related to the social exclusion of domestic violence victims - specialised work with families and couples.

The Animus Association Foundation offers a 24/24 helpline that is the most popular and accessible programme for survivors of violence. For many clients, the helpline offers the only opportunity they have for emotional support and understanding while retaining their anonymity. This service is for women who live in a situation of violence but are not ready to take the steps required to change it; women who have noticed the first signs of domestic violence and need consultation; women victims of violence who need assistance to make a decision. The helpline has a specialised assistance database that women can take advantage of when facing specific difficulties. In a crisis situation, following a recent occurrence of violence, the helpline consultants develop a security plan and refer the client to the Crisis Unit or to another appropriate programme. Most of the women call the helpline after instances of domestic violence, sexual violence or trafficking. The helpline also provides prevention information to young women planning to travel or work abroad and free legal consultations for women survivors of violence. A volunteer with a law degree gives these specialised consultations. The first contact with the centre is established through the helpline. This line was opened in October 1997, it receives on average more than 1,500 calls per year.

\footnotetext{
${ }^{13}$ Animus Association (Sofia), Demetra Association (Burgas), SOS - Families at risk (Varna), Bulgarian Gender Research Foundation (Sofia, Plovdiv, Haskovo), PULS (Pernik), NAYA Association (Targovishte), Ekaterina Karavelova Association (Silistra), Bulgarian Fund for Women (Sofia), Alliance for Protection against DV.
} 
In cities where there are active NGOs, agreements are signed between these NGOs and the courts to deal with perpetrators of domestic violence through appropriate programmes. These programmes are insufficient - they are only offered by five $\mathrm{NGOs}^{14}$ in the country. In addition, the Open Doors Association in the city of Pleven has ceased activity after 13 years of social work following a conflict with the municipality.

In cooperation with the Gender Alternatives Foundation, the Animus Association Foundation conducts periodic training seminars for social workers from community support centres. These two foundations also develop and publish a training manual for social workers. The website of the Animus Association Foundation provides access to "Sample standards and methodological instructions for working with domestic violence cases within the boundaries of community social services".

Police officers have been trained mainly by NGOs on DV issues and on supporting victims. For example, during 2016, more than 500 social workers, police officers and trainers were trained to handle cases involving DV. In 2016 and 2017, 180 police officers participated in three national training seminars on improving the legislative framework and harmonising with European standards in the field of DV. In addition, two training guides were published with the help of European experts.

The most common format is that of NGOs organising a training course lasting several days that brings together different types of stakeholders in the field of DV. This is particularly the case for the PULSE Foundation in Pernik, which regularly organises training courses with support from the Ministry of Justice. This type of seminar brings together police officers from the General Directorate of the National Police, the Regional Directorate of the Ministry of Interior (Pernik), social workers from the Social Assistance Directorate and the Child Protection Directorate of the small towns of Pernik, Radomir, Breznik and Tran, as well as representatives of the Regional Directorate of Social Assistance and family lawyers from the city of Pernik. Participants work together on DV cases, build role-playing games, share their professional experiences and work on the publication of a pocket guide for police

\footnotetext{
${ }^{14}$ Bulgarian Gender Research Foundation (Sofia), Demetra Association (Burgas), SOS-families at risk Foundation (Varna), Animus Association Foundation (Sofia), PULSE Foundation (Pernik)
} 
officers. The themes discussed are: different types of violence, perpetrator-victim relationships, crisis intervention and the effectiveness of intervention measures.

Generally, the participants are satisfied with this training format, but they highlight weaknesses that compromise the success of the training: Participants are not notified well in advance, and the police respond in a rather urgent manner to find participants. Consequently, the GDNP appoints police officers who oversee DV cases to participate in training organised by NGOs. The participants are often the same, and there are also police officers "subscribers" 15 at the training, which compromises the effectiveness of the knowledge and the know-how transmitted.

Even though professionals from institutions receive annual training in the field of domestic violence, there is no consolidated training programme to build capacity, skills and cooperation between different specialists on the topic of domestic violence. There is also no database of good practices, methodologies and recommendations.

Most of the funding for training programmes comes from European programmes, international projects and the Norwegian Financial Mechanism.

\section{Case study of PULS Foundation: good practices to deal with the State's failures in the fight against DV at local level}

In post-totalitarian Bulgaria, interpersonal links are more effective than interinstitutional relations, communication between public actors suffers from systemic difficulties and the oral tradition has a strong influence over the written culture. In this context, the non-governmental sector plays a pioneering role in the implementation of actions for the public good, in general, and policies for the protection of victims of domestic violence, in particular. Because of their organizational and operational flexibility, as well as their local roots and the support of national and international networks, NGOs have established themselves as actors of democratic change. The case of PULSE Foundation in the city of Pernik is an example of good practices built on individual initiative and personal involvement on international, national and local level. This NGO plays an important role in the

\footnotetext{
${ }^{15}$ Police Officer from General Directorate of National Police interview in Sofia, February 2019.
} 
protection of DV victims and thus helps to overcome the shortcomings of State policies in this area.

PULSE Foundation is registered in 1999 under the name "Animus" - Pernik to underline its relationship with the "Animus" Association in Sofia, which gave rise to the idea of creating a similar NGO outside the capital. Its goal is to promote a society based on non-violence and equality of the genders. Since the beginning of 2002, the organization continues its charitable activity under the name "PULSE" - "Positive Personal Skills in Society". Since its creation until today, PULSE continues to benefit from significant international support. Its most important aid provider was the GIZ (former GTZ) - Deutsche Gesellschaft für Internationale Zusammenarbeit. The Foundation was created by three young women which were working as therapists and all volunteering with a women's rights organization in Sofia, the capital of Bulgaria. They noticed that a large proportion of the telephone calls that they were receiving came from women in Pernik. That's what compelled them to create their own organization in Pernik. Their idea was to promote a society based on non-violence and equality of the genders. Its slogan is "The best way to fight violence is to create conditions where it won't happen".

The key factors for the success of the PULS Foundation's actions are: the commitment of its members - professionals and volunteers - and their support by national and international networks fighting against DV; the implementation of a wide range of actions aimed at priority categories of public; its role in steering the fight against DV at local level; the presence of specific people playing the role of specialized relays in the partner organizations; the sharing and processing of information within the partnership networks, as well as the effort to train stakeholders and produce knowledge.

The priority of PULSE Foundation is to create and affirm effective regional care programs for children, adolescents, adults and their families who have suffered or are at risk of violence. The service offers two types of activities- prevention and rehabilitation. The first one refers to the existing attitudinal and institutional biases in cases of domestic violence and child abuse, and adopts an educational approach and planning for community facilities. The second one refers to identified cases of violence and adopts an individual and family approach (Bassett ETZ AL. 2011). 
Thus, PULS offers its services to a wide range of categories of victims or perpetrators of domestic violence, seeking to specialize its effectiveness so that each case can be treated individually. The Foundation works with the following target groups; people, affected by physical, psychological or sexual abuse; victims or potential victims of violence or trafficking, or other forms of exploitation; children, living in dysfunctional families, with antisocial behaviour, homeless children and adolescents in hazardous environments; Roma community; drug addicts; adolescents and young people at risk; general public. Efforts are concentrated on helping the most physically threatened victims and the most dangerous perpetrators.

In the region of south-west, the PULSE Foundation and « Animus » are the largest organizations that have the capacity to shelter victims. They often work together especially regarding the creation of a Crisis center. A Crisis center was opened in 2008 within the building of the Foundation. It has been specially adapted to the rehabilitation program. The Crisis center is on the first floor near the rooms for psychological and legal consultations. The location is secured as well as it provides a safe environment for people in an acute danger. A group of specialists works with the abused to overcome their psychological traumas, provides them with support for official documents and assists their daily needs. The Crisis center provides a 24hour service.

The most developed partnerships - corresponding to projects in which PULS is a pilot or partner - pursue several targeted programmes simultaneously that address different problems such as, for example, domestic violence among migrants and refugees, protection of children and adolescents who witness violence, forced marriages and honour crimes. Each of these problems is handled by a dedicated team and benefits from the support of the actors involved and specific working groups.

Considering the inefficiency of the National Coordination Mechanism and National Program against DV, PULSE Foundation took the initiative to set-up a Regional Coordination Mechanism to work in cases of domestic violence. The Convention for cooperation between institutions and organizations in Pernik District was signed in December 2016: at the end of 16-day global campaign for action against DV all participants agreed on the idea of timely, adequate and coordinated assistance to victims. The partners in this agreement are: Municipality of Pernik, Child Protection 
Department- Pernik, Social Assistance Directorate- Pernik, Regional Police Directorate- Pernik, District Court- Pernik, Regional Inspectorate in EducationPernik, Regional Inspectorate for Public Health Control- Pernik, KABKIS (Room for Free and Anonymous Consulting and Examination of HIV/AIDS)- Pernik, Hospital "Rahila Angelova", Bulgarian Red Cross. Two and a half years after the implementation of this agreement, the results do not quite match expectations at the time of signing.

Since the establishment of the Regional Coordination Mechanism, PULS tries to organize two meetings per year with the signatories. These consultation meetings are crucial in the fight against DV because the partners have to agree on how to respond effectively to concrete cases of DV. The inter-professional dialogues make it possible to build a common vision of situations and to develop joint operational solutions. During these processes, the participants accept the external viewpoint of the other partners, but the question of control from another institution remains thorny. One of the reasons for this is the weak assessment culture within the institutions. Indeed, the assessment of weaknesses and strengths is not part of the internal paradigm of public actors. As a result, some partnerships - e.g. with hospitals - find it more difficult to adopt a constructive approach to agree on the treatment of DV cases. According to the testimonies of PULS members, progress has nevertheless been made as emergency departments are dealing with DV cases in a more discerning and prompt manner.

Not all partners who support PULS in the collaborative arrangement adhere to the coordination initiatives with the same level of commitment. The attention paid by the police to DV issues increases over time, but local police see the Law for Protection against DV as secondary. In order to better protect victims, police officers consider that actions in case of DV should be included in the police's internal regulations. In fact, the chain of assistance for victims is sometimes broken at the first contact with the police, both for reasons related to the difficulties inherent in the functioning and the recent past of this institution. Due to endemic corruption, the opinion that services for disadvantaged people are deficient compared to those for influential people with relationships predominates. Concerning the interactions with the judicial system the members of PULSE deplore the impossibility of shortening judicial delays, which leads victims renouncing to continue the process. 
PULS is hindered in its actions by the fact that not all the partnership relays have a high status or adequate resources allocated by the respective organizations. For example, within the police, the regional coordinator of actions against DV does not have autonomy of action or particular influence with his management. The reason for this is the absence of an internal police regulation that gives prerogatives to police officers specialized in DV issues. For their part, the police officers in charge of the DVs do not have any specific devices to facilitate their tasks or encourage them in the exercise of their duties. On the other hand, these police officers are disappointed by the long time it takes for investigators to gather all the evidence required by the prosecutor. The prosecutor is not inclined to pay particular attention to DV cases. Its involvement in the Regional Coordination Mechanism does not show any specific engagement. Collaboration with the Police and the Prosecutor's Office is also more difficult because the focal points have no leverage to ensure that their institution complies with the commitments of the Regional Coordination Mechanism.

The PULS Foundation is one of the first regional organizations to be contacted by both victims and institutional partners in cases of DV. It has a database of all persons - victims or perpetrators of domestic violence - who have used its services. The data is collected by means of forms filled in each time a person is received by the Foundation. As the Foundation has been developing its activities for more than twenty years, these data are sufficiently complete to represent an operational tool at regional level. In the best of cases, it allows us to quickly identify people who are at risk and to evaluate the strategies to be adopted in order to shelter them in case of reported violence. If, on the other hand, the person in question is not known to the Foundation, the latter can contact the regional police to broaden its search.

The first contact with DV victims is quick and effective. PULSE Foundation operates his hotline (+359 7660 1010), it can be contacted also via e-mail. Women at risk and social workers from the whole country call the number for legal, psychological and social assistance. PULS remains one of the few possibilities to accommodate DV victims because, overall, Bulgaria does not fulfil the Council of Europe Recommendation of safe accommodation in specialised women's shelters. 
The fight against DV and in particular PULSE's actions are put in difficulty by the insufficient awareness and training of front-line officers in dealing with DV. In particular, this is the case for the local police hotline. A single agent handles all calls and has to deal with six phones on his own. Therefore, he or she cannot handle all calls, especially at peak times during weekends and holidays. Fot this reason, certain emergency cases do not receive an adequate response. The situation at times of many calls can quickly become impossible to control when the duty officer does not have much experience and lacks appropriate training. Our request to observe the work of this call centre over a weekend was not approved by the local police chief.

\section{Conclusions: main challenges and issues}

The most important reforms in post-communist Bulgaria came through the action of foreign actors, especially following pressure from the European Council to meet EU standards. As a matter of principle, the country's problems have been received effective solutions when recommendations from international organizations served as a sounding board for the agenda of national stakeholders.

However, in the field of protection against domestic violence, a majority of the population adhering to "traditionalist values" hardly conceals their feelings of homophobia and intolerance towards "negative practices" from Europe. The decision of the Constitutional Court on July 27, 2018, proclaiming the unconstitutionality of the Istanbul Convention was the paroxysm of this atmosphere marked by the rift between two opposing social visions of family values. Civil society defending women's rights qualified this decision as "the worst decision of the Constitutional Court in its history".

Currently, institutions and people involved in the DV processing chain are in fact working as part of an already well-defined mechanism, but there are significant gaps in its operational functioning. The main cause remains lack of political willpower to build a sustainable framework for the care of victims and perpetrators of violence. This is also one of the main reasons why there is no evaluation of the state of domestic violence or procedures to assess particular situations from the point of view of the risks incurred by the victims. Furthermore, the chain of assistance for victims is often broken at the first contact with the police, both for reasons related 
to the recent communist past and the difficulties inherent in the functioning of this institution.

In such a hostile environment, the work of frontline responders to DV is made difficult by several reasons. The lack of a national data base of registered cases of domestic violence is seen by police authorities as substantially hampering their work in the area. There are local exceptions where the police establish their own database but the benefits remain limited. Another difficulty comes from the lack of structures of safe accommodation in specialized women's shelters. At the national level, only six crisis centers managed by NGOs are operational.

On the national level NGOs working in the area of protecting and assisting victims of domestic violence, make several recommendations:

- Awareness raising and education should be done among all stakeholders, including police and courts, about the specificities of domestic violence and their own powers in protecting its victims;

- Swift communication should be existing among institutions, preceding official correspondence, so that timely co-ordination takes place;

- Directors of local Social Protection Directorates should use their powers to initiate proceedings for issuing protection orders for each case of domestic violence against children, persons under legal guardianship and persons with disabilities;

- When urgent reaction is needed, especially regarding children victimized by domestic violence, the specific law on domestic violence should have priority over other legislation, because it allows for a swift protection procedure, while long-term measures can be devised later;

- It is sufficient that there has been at least one previous case of violence to initiate criminal proceedings. And in serious cases - beating, medium and serious bodily injury, it should not be examined whether there have been previous cases in order to initiate criminal proceedings;

- Risk assessment should be part of a broad training and enforcement effort in the field of DV;

- Systematic monitoring of the implementation of the specific law on domestic violence should be in place. 
The most important recommendation of national police officers concerns the establishment of social workers within the Police to improve the reception of victims of DV and help police officers in the long-term assistance of those cases.

\section{References}

Ivanova, S. (2016). National Study on Domestic and Gender-Based Violence in Bulgaria Analytical. Sofia, Partners Bulgaria Foundation.

Bjørnsen, G., Nesheva, E., \& Ilcheva, M., (2015). National Study on Domestic and Gender-Based Violence and Elaboration of a Victims Support Model: Legal, Institutional and Policy Analysis. Sofia, CSD.

Ilcheva, M. (2018). Mapping the Legislation and assessing the impact of Protection Orders in the European Member States. Sofia. CSD.

Nesheva, E., Kolarova, D., \& Minkovski, R. (2016). Domestic and Gender-Based Violence: Victims Support Model. Sofia, CSD.

Tisheva, G. (2005). The Law on Protection against Domestic Violence - A Breakthrough in the Division between Public and Private Sphere in the Protection of Human Rights in Bulgaria. Legal Thought, 2, 112-122.

Dimova, R., Kmetova, T. \& Alii. (2015). In Response to Violence Against Women: a Guide for Companies against Gender Violence. www.carve-daphne.eu

Avon Womens Foundation. (2019). National bigh school survey on violence against women. https://www.avon.bg 
